\title{
To and fro : international cooperation in research and research on international cooperation
}

Citation for published version (APA):

de la Rive Box, L. (2001). To and fro : international cooperation in research and research on international cooperation. Maastricht University. https://doi.org/10.26481/spe.20011012/rb

Document status and date:

Published: 12/10/2001

DOI:

10.26481/spe.20011012lrb

Document Version:

Publisher's PDF, also known as Version of record

\section{Please check the document version of this publication:}

- A submitted manuscript is the version of the article upon submission and before peer-review. There can be important differences between the submitted version and the official published version of record.

People interested in the research are advised to contact the author for the final version of the publication, or visit the DOI to the publisher's website.

- The final author version and the galley proof are versions of the publication after peer review.

- The final published version features the final layout of the paper including the volume, issue and page numbers.

Link to publication

\footnotetext{
General rights rights.

- You may freely distribute the URL identifying the publication in the public portal. please follow below link for the End User Agreement:

www.umlib.nl/taverne-license

Take down policy

If you believe that this document breaches copyright please contact us at:

repository@maastrichtuniversity.nl

providing details and we will investigate your claim.
}

Copyright and moral rights for the publications made accessible in the public portal are retained by the authors and/or other copyright owners and it is a condition of accessing publications that users recognise and abide by the legal requirements associated with these

- Users may download and print one copy of any publication from the public portal for the purpose of private study or research.

- You may not further distribute the material or use it for any profit-making activity or commercial gain

If the publication is distributed under the terms of Article $25 \mathrm{fa}$ of the Dutch Copyright Act, indicated by the "Taverne" license above, 
TO AND FRO 
OLouk Box, Madstrich 2001

ISBN 9052783284 


\title{
TO AND FRO
}

INTERNATIONAL COOPERATION IN RESEARCH AND RESEARCH ON DNTERNATIONAL COOPERATION

\author{
Inaugural lecture \\ presented in an abbreviated form \\ upon the acceptance of the position \\ of Professor in International Cooperation \\ at the Faculty of Cultural Sciences \\ Maastricht Uniwersity \\ October $12^{\mathrm{b}}, 2001$
}

\section{Louk Box}

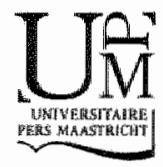



When the first US envoy to Japan presented his credentials to the Imperal Court, two interpreters were present: one to translate English into Dutch, and the other one from Dutch into Japanese. Why? Japan had chosen Dutch as its preferred foreign scientific language in the preceding century. Dutch provided a window on the world of contemporary science, just as Latin had done so before in Europe. Japanese doctors were sent to the Netherlands to get advanced medical training, and so were people from other disciplines. ${ }^{2}$

When I recently interviewed Professor Bredekamp, the South African expert on the Khoisan and a member of that ethric community, he informed me that he had enjoyed the collaboration with a Dutch institute in a study on the Khoisan Revival Movement. They were partners in Sanpad, the South Africa-Netherlands Research Programme on Alternatives in Development. I was surprised to learn that a Dutch research institute had contributed to a study of members of this community, formerly known as Bushmen and Hottentots. ${ }^{3}$

Why am 1 telling you these stories? Because in a way, these relations with Japan formed the start of sustained Dutch bilateral cooperation programmes in science and technology. Granted, there were many exchanges in science and technology in the $17 \mathrm{th}$ and 18 th centuries; the world of science was then as open as it is now, possibly even more so. The relationship with South Africa

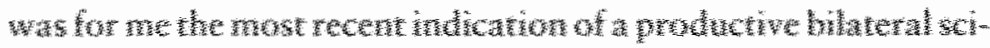

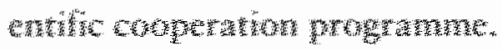

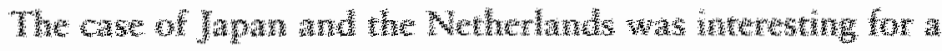

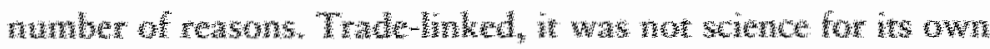

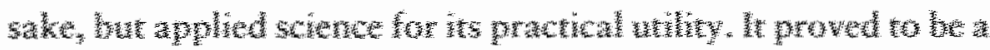

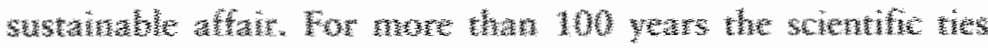

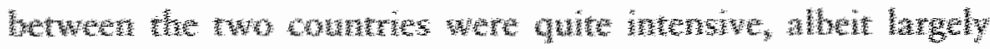
ane-wata 
The relation with Japan did not stand by itself. The Dutch were the first to establish a colonial Society of Arts and Sciences in Batavia, the capital of the Netherlands Indies (Bataviaasch Genootschap van Kunsten en Wetenschappen) in 1778, that was six years before the British established an Asiatic Society of Bengal. Another 'first' was the establishment of the Colonial Institute KIT in 1850, well ahead of the Scientific and Practical Department of the London Imperial Institute in 1894 (Gaillard 1999: 268-269). Wageningen University developed in the end of the 19 th century, to build capacity for tropical agriculture (not: in the tropics), and until the 1940s Leiden University boasted a strong colonial administration department (not: to build local capacity). The tropical roots of these institutions go deep into Dutch colonial history. All of this is largely forgotten, yet it illustrates one small country's long history of involvement in tropical research. Development cooperation may be young as a social phenomenon, but its past is long and needs to be better understood.

Cooperation in science between East and West or, as we presently say North and South, therefore has a respectable history. It is also a relevant phenomenon now, and I hope it will remain so in the near future. Just one statistic to show its current relevance: it is estimated that about $5 \%$ of all Official Development Assistance is spent on scientific and technological cooperation. That amounts to about 3 billion Euros per year. In a good number of poor countries it forms the lifeline for Southern scientists who wish to remain part of the global knowledge network. In this lecture I wish to show some trends in this phenomenon and to test some views.

The trends have been well documented in a recent Human Development Report, which deals exclusively with international cooperation in science and technology. It argues that "Technology networks are transforming the traditional map of development, expanding people's horizons and creating the potential to realise in a decade progress that required generations in the past". 
Despite the overblown language, the message is fascinating. The report links technological transformation to globalisation and concludes that together they are creating a new paradigm: the network age (UNDP 2001: 27).

In this lecture I would like to test a few assumptions. The first one I shall call the transfer assumption. It states: Poor countries need transfer of knowledge and technology from rich ones because they cannot produce these themselves. The second one is the professional knowledge assumption. It goes as follows: Poor countries need professional, objective knowledge to end their dependence on traditional knowledge. The third assumption is the empirical basis assumption. It says: Empirical research on international cooperation in science and technology provides the basis for effective policymaking.

These three assumptions share one drawback: they say what we already seem to know. This is one of the apparent weaknesses of social science research: it confirms what we knew all along. And if it does not confirm common sense, it provides no clear indication of how to change things. Let me try to show that such common sense is a poor guide and show why the three assumptions are in dire need of revision.

I shall argue that the transfer assumption is hopelessly outdated (and has been so ever since development cooperation started), because the simple technology transfer model on which it is based has not worked. This means that we shall have to look at other models if we wish to narrow the technological gap between rich and poor countries. I shall try to show that professional knowledge is intricately linked to particular assumptions, which may not hold everywhere. In fact, I will argue that the gap between so-called formal or professional knowledge and amateur, artisanal, indigenous or traditional knowledge is large and significant. Professionals need amateurs, and vice versa.

Finally, empirical studies of public international cooperation in science and technology are conspicuous by their absence. There 
is, however, much empirical work on the economics of innovation at the level of the firm or at the cluster and national levels. Another body of literature deals with the need for dialogue between the producers and users of science and technology. We may be able to adapt that literature to see what it means for the ropic of today: international cooperation in research and research on international cooperation in science and technology.

From this I conclude that such research is urgently needed. The lecture is built around three panels, like in a triptych. Let me open the first of three panels, the side panel on international cooperation in science and technology, depicting the so-called transfer of technology model.

...modern science appears akin to an imported brand of toothpaste.

It contains elaborate promises and mach sweetness and glamour. It can be used, is often wed (pointlessly), yet can be dispensed with at any time precisely because it is still largely irrelevant to life. Claude Aluares (1997)

FROM TRANSFER TO COOPERATION

Development cooperation, as we knew it, was rooted in many different soils. First and foremost, it emerged from the immediate post-World War II programmes of reconstruction and development in Europe and North America. Inspired by Truman's 'Point Four' of 1949, a singular mix was proposed involving transfer of know-how and technology. Truman announced a "bold new program for making the benefits of our scientific advances and industrial progress available for the improvement and growth of underdeveloped areas" (Ponsioen 1968: 52). Bold it was, and lasting would be its effects. Not only in "underdeveloped areas' but also in the policies and programmes of the countries that would become known as the 'developed', the 'industrialised', the North, 
the donors or simply the "rich". The assumption was simple: countries are developed because they are scientifically advanced and therefore industrialised. Underdeveloped countries lack knowledge and therefore that knowledge needs to be transferred first. Capital transfers play only a secondary role and would come from private sources. ${ }^{4}$

There is much to be said for the simplicity of the model. After all, the so-called underdeveloped countries had generally been colonies of the European powers that had not created what we would now call a 'knowledge base'. On the contrary, almost all higher education and scientific research was concentrated in the metropolis. Some applied research did occur, especially in tropical agriculture, focusing on particular crops like cotton, coffee, cacao, rubber and tea. Since these colonies had been starved of 'scientific advance', it was logical for Truman to assume that the gap needed to be closed by a transfer of scientific knowledge to allow for 'industrial progress'. The thinking in the rival camp, led by the former Soviet Union, was no different in this respect: promote industrialisation on the basis of knowledge transfer.

This was the context for the start of development cooperation, as we presently know it. In October 1949, the Netherlands was one of the first donors in the world to follow Truman's lead. Interestingly, it took the form of support to the United Nations' Expanded Programme for Technical Assistance. The motivation was rather self-centred. Dutch aid would serve a national economic interest because it allowed Dutch scientists and entrepreneurs new opportunities for exporting knowledge and products. In addition, it might enhance international prestige. Last (but certainly not least), it could provicle work for the many colonial engineers who had been unemployed since Indonesia became independent (Malcontent and Nekkers 1999: 12). The conclusion must be that the genesis of Durch aid was couched in Dutch inter ests, including scientific and technological interests, articulated through US policy priorities. What could be more logical than to 
transfer that 'unemployed expertise' to countries that apparently needed it?

The Dutch case was no exception. Ponsioen (1968:57) notes: "if development assistance was new in 1949 , it suddenly was present in 1950 the world over". It was generally assumed that knowledge was abundantly available in the developed countries and that sending experts to, or training students from, the devel. oping countries could do the job. This assumption was confirmed by leading theoreticians of the time, the so-called 'modernists'. The leading ideologist, and author of "a non-communist manifesto", argued that countries first needed to pass a stage of 'take off to self-sustaining growth' (Rostow 1960). Not surprisingly, he argued for technical assistance. In other words: modernisation and technology transfer were two sides of the same coin. Modernisation theory provided the rationale for this particular form of aid.

Quite soon, however, the model proved to be dead wrong. Experiences in the early 1950 s showed that "the technical knowledge, required in tropical countries, was not available in the West, or at least not readly for its application in other than Western conditions" (Ponsioen 1968: 60). Nevertheless, the technology transfer model continued to inspire aid or cooperation policies for decades to come. A model that was outdated at the outset was to inspire generations of policymakers, scientists and technologists, be they diplomats of the $1940 \mathrm{~s}$, industrial engineers in the $1950 \mathrm{~s}$, or biotechnologists in the 21 st century. Was the Indian writer with a deep mistrust of the 'modern knowledge industry' Claude Alvares right when he compared science with toothpaste, and dismissed them both as 'irrelevant to life'?

Why recount this early history? Because it shows how scientists and technologists have been involved from the very start in the shaping of official development aid: they had a stake in it (as unemployed experts in Europe) and they helped shape its rationale or theory (as in Rostow's work). Claude Alvares (1997:294) 
has attacked these unholy allances between science and the state, as imposing an element of Western culture over poor conntries.

Scientific interest has interacted with the rationale for technical assistance. Rostow's modernisation theory provided a basis for technology transfer, and made for a very special type of donor support that suited particular interests. I do not subscribe to a conspiracy theory, which argues that scientists from developed countries only saw it as being in their interest to prowde this type of aid. Aid has always had too many interests or motivations assom ciated with it to just link it to one interest group.

1 would point out, however, that a close relation has existed between science and development aid from the very start in the late 1940 s, and that a theoretical model was adopted in which science was accorded a special place in the development process. "The model continued to be operative, even though its faults soon became evident. What, then, was different from those other types of scientific and technological collaboration berween Japan or South Africa and the Netherlands? Allow me to open the second parel of the triptych, which deals with different views on formal science and informal knowledge networks.

Mach of the knowledge that is required for successful development

is not patentable.

Joseph Stiglitz (1999: 318)

FORMAL SCIENCE AND

INFORMAL KNOWLEDGE NETWORKS

Poor countries need professional, objective knowledge in order to end their dependence on traditional or local knowledge. Or do they? If the transfer model is outdated, as observers argued even in the 1950 s, then surely this assumption needs serious 
review as well. The question thus becomes: what have we learned about the role of formal science in international cooperation? Formal science, seen as a body of knowledge, is incorporated in a profession, and validated by the rules accepted by that profession. This is the topic of the second, or middle panel of the triptych.

\section{Formal science: a profession of faith?}

From a social perspective, science can be seen as a profession: a vocational grouping that is characterised by shared standards of technical skill, a view on the role in society and the institutions to further them. The sociologists Merton and Shils see it as "the institutionalisation of an intellectual activity... the relatively dense interaction of persons who perform that activity. The interaction has a structure: the more intense the interaction, the more its structure makes place for authority which makes decisions regarding assessment, admission, promotion, allocation" (in Cernea, 1991: 33).

With the increasing role of science and technology in society throughout the 19th and 20th centuries, the scientific profession has obtained a novel status or influence. With the advent of the so-called global knowledge society, the status of science and technology and the related knowledge has become even more important (De Wilde 2001). This has affected the rich countries, but is also affecting the newly independent countries in what used to be called the Third World. A rapidly changing concentration of scientific progress and technological innowation has happened over the past decades, fundamentally changing the place of science and technology in global society.

The UNDP Technology Index shows that the "Third World ain't what it used to be":

- In 1995-97 the share of tertiary enrolments in the natural sciences in developing countries was about equal to that in the high-income OECD countries (UNDP 2001: table 2.5). 
- The geographical distribution of technological innovation is changing rapidly: Taipei is now among the top ten global hubs of technological innowation; Bangalore comes before New York and well before Tokyo and Kyoto (UNDP 2001: Map 2.1).

- The top 10 leading exporters of hi-tech products in global markets include four countries that used to belong to the category of less developed countries (Singapore, South Korea, Malaysia and China) (UNDP 2001: Table 2.6).

- An increasing differentiation is occurring within countries. India ranks 7 th in the world in terms of the number of scientists and engineers it produces, yet the adult literacy rate is only $44 \%$. It is one of the largest exporters of brains $(100,000$ per year to the US alone), yet it continues to increase its science budget (to about Euro 3 billion in 2001; see Jayaraman 2001). It boasts a technology hub in Bangalore, yet it is among the lowest dynamic adopters of technology, behind Zimbabwe (UNDP 2001: Map 2.1).

These examples illustrate the new inequalities between and within countries. Science and technology can develop very rapidly, and can truly provide a global market for knowledge. The rich countries do not apply restrictive labour policies, as they do for manual or skilled labour. This means that thousands of Indians and Chinese are working in Silicon Valley, engaged in so-called ICT (or 'Indian and Chinese technology') in highly mobile positions in the diaspora, with possible spin-offs for their countries of origin. Paradoxically, the Chinese government has hired foreign scientists over the past three years and has invired 500 foreign scientists to take up posts in the country ( $\$$ cott 2001).

Increasingly, therefore, global competition exists for these scientists, attracting them to islands of knowledge that may exist in an ocean of misery. Instead of mitigating or tackling inequalities, technological development in these cases contributes to inequali- 
ties. We know that these inequalities have increased tremendously over the past decades (Human Development Report 2001: Fig. 1.6). And we know that the global knowledge market is exacerbating them through the brain drain, which takes for example 1 out of every 3 educated Africans away from their country of origin (Adeboye 1998: 180).

This globalisation of the market for knowledge has other effects as well. A different model of technology development appears. It has been argued (Feil 1994: 446-47) that "a fundamental reversal in the dynamics of technology transfer" is taking place, with the result that "industrialisation and economic growth can take place without a sound scientific basis". A 'de-linking' of technology production and consumption occurs through the activities of transnational companies making deals with local affiliates. These deals can take the form of joint ventures, mergers and acquisitions and may have benefits for the poor country in question - but only in the short run. The sustainability of such ventures is likely to be low, as Mytelka (1998: 13) has shown. "Sustainable scientific research without close links to technology is just as unlikely as growth of advanced technology without a scientific basis" (Feil 1994: 447).

Add to this problem the irrelevance of formal science to solve problems in poor tropical countries. Take the case of medicine: of the 1223 drugs marketed worldwide between 1975 and 1996, only $1 \%(13)$ were developed to treat tropical diseases. Out of the 95,000 articles published in medical journals in 1995, only one-fifth of one percent (182) dealt with tropical diseases. Out of the global spending on health research, only one-fifth of one percent concerned pneumonia and diarrhoea, which together account for $11 \%$ of the global disease burden, especially in poor countries (UNNDP 2001). This is the case for medicine, but in environmental science the situation is not likely to be much better. Traditional centres of tropical agricultural science in Europe have 
either closed their doors or have become dependent on consultancies (Gaillard 1999: 40-43).

The problem is aggravated by the perceived trelevance of raditiona science, especially in many African countries. Pawin Hountoundi, a respected African phlosopher, calls this "mimetism" or an extreme attentiweness "to the intellectual fads of the West". His wiew is that African research has been "ircelewant" for two reasons. "One was the oppositional stance of most African intellectuals and their unwilingness to be "usable'. [... The second, and more serious problem was whether our basic research really addressed the key issues and whether, when it borrowed concepts, it was sufficiently sensitive to the specific of our own condrons" (cited in Mkandawire 2000:211).

All in all, this is quite an indictment of traditional science: it could be irrelevant, and when relevant it might exacerbate the cleavages between rich and poor.

Towards a new approach: is local knowledge the answer?

The question that therefore needs to be asked is: is the type of knowledge that modern science produces to blame for this? Could it be that another type of knowledge would be more tele vant to the needs of the poor in poor countries and produce less inequalities as just signalled? 'This is a question that has increasingly occupied social scientists, especially those interested in the questions rased by Clatde Avares and others. Authors like Gibbons (1994) have argued that the very nature of knowledge production in rich countries made it inapplicable among the poor elsewhere. Especially in the agricultural sciences, these arguments have been made and have led to a blossoming of different views and the proposal of countless approaches and techniques to overcome this.

Gibbons and his colleagues (1994: 1-3) have argued that two mades of knowledge production can be distinguished. A Mode 1 
exists in the traditional context of the scientific profession, along disciplinary lines, following the Newtonian model. The setting is the homogeneous academic community, its hierarchical structure and its corresponding interests. It is accountable largely to itself, setting the standards of 'sound scientific practice'. It is the type of science that Alvares discarded as being largely irrelevant to life, because it was not rooted in the local cultural context. Toothpaste, in other words.

Contrast this with a new paradigm, or an emerging Mode 2 of knowledge creation. Gibbons' team saw this as the coming trend. Generated in a context of application, involving a trans-disciplinary approach by practitioners from various backgrounds, it is marked by its heterogeneity. Not the academic community of scholars primes, but the broad community of people interested in solving a problem. Not academic accountability, but social accountability. Not global models, but local problems form the starting point. In Alvares' terms, a mode of knowledge production that is not associated with a coercive state, but with a supportive community. Nor toothpaste, but food; food for thought.

The clash berween these trends has been fierce. I recall the debates in agricultural science in the late 1970 s and early 1980 s. Mode 1 identified itself as the only science that could help solve major problems like world hunger. It produced a Green Revolution, which increased food production and rural inequalities at the same time. Mode 2 saw itself as the protagonist of the poor, solving the problems through the involvement of 'the people themselves'.

At the time I designed an adaptive agricultural research programme involving plant scientists, soil scientists, economists and social anthropologists. My naive belief was that there must be a middle road between the simplistic rhetoric of the disciplinarians, in which reality was reduced to a mathematical model, and the naive idealism of those who reduced reality to indigenous knowledge. After all, the poor farmers we were working with 
wanted to know solutions from us based on scientific experiments. They were puzzled when we were interested in their solutions based on their elementary experiments. They might not even recognise their own experiments as such, calling them thorse play'. My colleagues at Wageningen Agricultural University tended to agree with those farmers: if sound scientific practice were irrelevant, then why would farmers adopt the resulting technologies? If indigenous knowledge and farmer experiments were so important, why did yields remain so low? I recall how my research proposal was rejected in the University by a colleague who said: "farmers don't experiment, so: no go".

While doing research in the Dominican Republic and in Costa Rica, I became convinced that the traditional Mode 1 did not explain reality. I also realised that Gibbons' Mode 1 and Mode 2 types of knowledge were not just trends, they were ideologies in the battle for the control of science. Especially in what was called 'science for development', or 'development-oriented research'. The modes were ideal types, easily transformed into battle cries. Simplification occurred. The view of reality could become blurred, especially if the views were translated into policies. Agricultural policies in most poor countries were still based on the premise of formal science and the transfer of technology as the solution to all problems. Pressure groups in rich countries and authors like Alvares pointed out that there were alternatives. Aid donors were caught in the middle, and development research would face radically new approaches in the 1990 s.

My view is still that there needs to be at middle ground. The rest of this lecture contains a plea for this view and draws implications for the associated research policies in international cooperation. 
The concept of "knowledge transfer" is theoretically madeatiate and practically dangerous [...]. "Networking" as a dywantic action-oriented concept focusing on engagenent, relationship. management and social interaction is a contender for replacing it.

Engel (1995)

Knowledge networks: a third mode?

While doing the research in the Caribbean and in Central America, I found trans-disciplinarity to be a noble goal, yet hard to take as a starting point. Most of my colleagues (national or expatriate) were hard working, well-intentioned professionals who were committed to general notions of poverty alleviation. They, like me, were good in only a few things. Yet, transdisciplinarity meant for the economist that he had to understand the value of case studies and qualitative analysis; for the biologist, that she needed to understand elementary econometrics, and for the soil scientist an understanding of farmer-led trails or experiments. The Mode 2 ideal of trans-disciplinarity, heterogeneity and organisational diversity was shared, but as a management goal it proved to be far harder to implement than expected. ${ }^{5}$ Add to this the demands of social accountability, or the answer to the question: who decides that we are doing the right thing in the right way? Involving the farmers proved to be hard enough; asking them to evaluate our findings or recommendations was at times impossible.

In Costa Rica we found that agricultural innovation appeared to be dependent on the nature of knowledge networks involving farmers, researchers and all those who mediated between them. The idea was associated with studies in rich countries, which had shown that the degree agricultural innovation appeared to be highly associated with the quality of communication between all the parties involved. In the Netherlands, potato breeding had shown remarkable results, due to a highly articulated network of 
amateur breeders linking scientists and farmers. The resulks of cattle breeding in the Netherlands, however, declined rapidly at the same time that local breeder participation was reduced due to government policies and the monopolisation of the breeding process. The potato network was an example of an open and dynamic one, in contrast to the cattle breeding, which showed closure and stagnation.

If knowledge networks could prove to be an interesting entry point to understand and promote technological innovation, it might be an altemative to the battle cries of disciplinary traditional science versus trans-disciplinarian approaches. After all, the important factor would not be the disciplinary or trans-disciplinary nature, but the type of linkages between the various participants. In other words, I argue in favour of a Mode 3, which stresses not so much the differences - academia vs. community, North vs. South, or traditional discipline vs. holistic approach but rather the complementarity between the two approaches in dynamic or innovative knowledge networks. (Note: In taimess it must be said that Gibbons et al. (1994: 161) also stressed the importance of knowledge networks in their Mode 2).

We found an initial confirmation of this complementarity when contrasting the relatively open knowledge network in cacao innovation (somewhat comparable to the Dutch potato example) with the hermetically sealed network of banana innowation (resembling Dutch cattle breeding in the 1970s). The dynamic cacao network involved dialogue between independent growers, traders, extensionists and (disciplinary) researchers. Banana mnovation was almost exclusively dependent on secret company research done abroad, which was then passed top-down to the contract growers. Disciplinary approaches could be quite productive in the cacao case, provided the growers were linked in the knowledge nerwork. Researchers could take their experiences, and sometimes their experiments, seriously; their knowledge 
could be exchanged like in the Dutch farmer study clubs, which lay at the base of Dutch agricultural innovation (Engel 1995).

The notion of a knowledge network is the key to these modes. I see a network as a relatively loosely structured form of cooperation, in which coordination is done through a horizontal exchange of information, lacking a clear hierarchy (see also Chataway 1999?: 9). It is composed of communication links between individuals or groups. The network notion stresses these linkages and allows participants to exchange information and attach meaning to it, thus transforming information into knowledge. In contrast with the dominant Mode 1 type of knowledge production, it stresses horizontal exchanges of information. In contrast with Mode 2 type of knowledge production it allows for disciplinary (Mode 1) knowledge generation and exchanges, as well as trans-disciplinary (problem-oriented) knowledge generation.

I argue therefore that the current trend appears to be a synthesis of the two modes. Knowledge is not just verified within the scientific profession (peer review), or just falsified on the basis of review in the context of application or use (user review). Both sysrems of quality maintenance are operative. Paul Richards (1994: $166)$ calls this type: "knowledge that is in conformity with general scientific principles, but which, because it embodies place-specific experience, allows better assessments of [local] risk factors". For example, cacao breeders in the Costa Rican agricultural research station had to make their scientific case within the community of professional plant breeders; in the knowledge network, users also provided them with the practical validation. It was the combination of these two that made for dynamic innovation. 
Allow me to draw a few implications from this line of thinking. First, this model bears a strong similarity to the learning model that has emerged in many schools over the past decades. Maastricht University was one of the first in Europe to adopt such a problem-based learning orientation. It is based on the notion that knowledge is not transferred, but exchanged. The top-down teaching approach in classical education was replaced by group learning. The teacher becomes part of a knowledge network where his or her insights are tested. The general problem orientation is approached through a disciplinary point of view, which has been verified through peer review.

Second, this orientation highlights one of the problems in this mode of knowledge production: the diversity of validation or falsification criteria. Traditional criteria to decide on truth and relevance no longer have absolute validity. Spaapen (1999:7) therefore argues, "The biggest danger of this new mode, with its network structure, is clearly that it jeopardises existing institutional interests and arrangements". Just as problem-based learning endangered the position of the traditional lecturer, the knowledge network model endangers the position of the traditional researcher. This means that a professional is needed, who pays attention to the social relevance of knowledge production and exchange. Whereas in traditional science professionalisation meant the acceptance of particular codes of conduct, as I argued before, in a knowledge network it "also entails the organised support of the activity from outside the particular institution and the reception or use of these results of the activity beyond the boundaries of the institution" (Shils, in Cernea 1991: 33).

A third implication: the knowledge network approach assumes an appreciation for joint learning. Potato growers were learning in their study clubs, but researchers were also learning through such clubs. Common learning means: common author- 
ship of the insights obtained. Arrangements will then need to be made to determine who is the 'autor intellectualis' of those insights. In traditional science the case is simple: the scientist or group of scientists who first publish can claim primacy. The technologist who first patents an invention can claim the proceeds. In the new mode of knowledge production this becomes much more complicated. Especially, I shall argue, for the type of knowledge that is the subject of international cooperation arrangements. Some examples may clarify this point.

When Dutch soil scientists in Vietnam discovered a certain type of soil deterioration, they described it and were the first to publish the findings. When I asked how they had found out about the phenomenon, it became clear they had followed a farmer's clue about the process. They had described the process, not discovered it. Was the farmer's name included among the authors of the publication?

When a Dominican plant pathologist discovered the incidence of a blue mould on tobacco in the late 1970 s, peers and the public widely (and rightly) hailed her. When I asked how she had found out about it, she acknowledged the clues she had received from the growers. She had 'certified' the disease, but had not discovered it.

These examples are indicative of a more general phenomenon: how to acknowledge the contribution of non-professional scientists to such knowledge networks? I shall argue that this problem needs to be tackled for both pragmatic and ethical reasons. If science is not a world to itself any more (as in Mode 1) and involves non-professionals (as in Modes 2 and 3), then these non-professionals have a right to profit from the prestige or the profits. This argument applies to the soil scientist in Viemam, but also to the pharmaceutical company that has engaged in 'gene hunting' (Juma 1989) and has appropriated a particular substance through the involvement of tropical farmers. 
It is striking to note how little formal science has acknowledged these types of insights, which are often gained through informal knowledge networks. The phenomenon has been well known throughont the history of science, because the distinction between 'scientist' and 'dilettante' is a farrly recent one. The word "scientist" was first used in English as an analogy to the word "artist' in 1834 ; dilettante is somewhat younger and stems from 1748 (Webster's Dictionary). Learned societies would have both categories among their membership, and stimulate their scientific curiosity. The diletrantes might even have a special role or name, Inke 'sneupers' in the Friesian Academy. "My colleague Jo Wachelder pointed me to the interesting sudies by Ame Secord (1994: 408) of so-called artisan-entomologists, zoologists and botanists in early 19 th-century Britan. She shows that these artisans, or workingmen, had extensive correspondence networks. Their letters provide "tangible evidence of their scientific skill and signalled acceptance by a wider community of their right to practice natural history". With the professionalisation of science, distancing has occurred between the two categories. Therefore, the role of the non-professional in discovery and invention may have become less and less recognised.

Yet, the trend may be reversed, for various reasons. In rich countries an ever-larger part of the population lads followed higher education, thus contributing to a democratisation of science and scientific knowledge. In many fields of scientific endeavour the role of the non-professional has continued, or has increasingly been acknowledged. In archacology the role of the amateur has been extensively debated, as well as in fields such as astronomy, history (especially local history), botany and plant breeding. In ongoing phenological research on the effects of climate change on flora and fauna in the Netherlands, for example, the principal researcher has requested the audience of a popular radio programme to teport the first sighting of a plant or animal in 
a given season. The research profits from the vast network of lay informants or observers who provide a wealth of informarion.

In poor countries, local informants become a recognised part of research teams. Take the case of the huge natural inventory complled by researchers from the Merck Company in Costa Rica, where local farmer informants were formally included in the teams (Brush 1998). Their knowledge was recognised in subsequent publications. The research would have been impossible without these trained lay informants.

In Africa, "recent studies point to the existence of rich indigemous scientific knowledge in many parts of the region. [...] The region's Materia medica of more than 1000 animal, plant and mineral products for the treatment of illness is a resource that Western-trained scientists are widely studying. [...] The challenge seems to be how to integrate this African indigenous knowledge [...] into mainstream analytical science" (Bass, quoted in Adeboye 1998: 177-178). Professor Hannes van Staden, a famous botanist from South Africa, has taken up this challenge in his current collaborative programme on traditional knowledge about medicine and the link to botany. His research design includes investigations. in collaboration with traditional herb doctors and nurses. Rejected at first by the funding agency for its unconventional approach, the research was subsequently lauded for its original design and results.

The success of these approaches lies in the careful linkage of a fairly traditional (possibly even disciplinary) knowledge with user (or practitioner) knowledge. The recognition of user knowledge is the key to its sustainability (Brush 1998: 764). The resulting knowledge network can be remarkably dynamic, as the Costa Rican and South African cases illustrate. It made good commercial sense to a transnational company like Merck - just as it made good scientific sense to the botanist Van Staden.

We could take this one step further, as indeed Stiglitz did when he argued in favour of due recognition of a global commons. The 
need to maintain a 'global knowledge commons', and its financial implications, needs to be formally recognised. This means that the formal financial recognition also needs to be organised. "The international community could similarly claim the right to charge for the use of the global commons" (Stiglitz 1999: 316). For indeed this is crux of the matter: the knowledge networks that could form the base for a new division of labour, will need to selthe the matter of public versus private goods. And once that is clear, recognition of contributions to and claims on this knowledge can be arranged. This is the more important, since "much of the knowledge that is required for successful development is not patentable" (Stiglitz 1999: 318; see also Brush 1998).

It is all the more surprising that there is so little empirical study of this phenomenon. What makes for a productive research dialogue between professionals and practitioners? How is tacit knowledge codified in the reams? Who needs to be trained in what type of skills? How was the contribution of practitioners recognised? I have not been able to locate comparative analyses on such practitioner-professional collaboration. There are the mentioned historical studies on the subject, and materials from agriculture and the environment, but no comparative studies. ${ }^{8}$ This is therefore one of the tasks that I wish to take up in the coming years.

Before closing this centre panel of my triptych, let me try to formulate a preliminary conclusion, which corroborates the logic of the field of Science and Technology Studies (STS) as developed by Wiebe Bijker and orher colleagues in Maastricht. I have argued that professional knowledge is intricately linked to particular assumptions, which may not hold every where. In addition, I have argued that the borderline between so-called formal or professional knowledge and informal, amateur or indigenous knowledge is large and significant. Professionals need amateurs, and vice versa.

Citizens are increasingly becoming involved in setting the boundaries of what is considered to be desirable knowledge (wit- 
ness the public debates on nuclear energy, socio-biology, DNA, gender equaliry, and genetically modified organisms). Linkages with citizen practitioners in research are also called for. Recognition needs to be organised in the form of practirioner participation in the spoils, be they financial or honorary. For example, would it not be appropriate to bestow an honorary Bachelor's or Master's degree on one of the farmers who participated in the research mentioned?

... knowledge for dewelopment gaes beyond the collection of best practices and the accumulation of successful aecdates... why do certain policies and practices work in some circumstances and not others? Thus research is a central element of knouledge for development. Stiglitz (1999: 319)

An empirical basis for development policy?

Let us now look at the third assumption, which states: empirical research on international cooperation in science and technology provides the basis for effective policymaking.

After a half-century of technical assistance and development cooperation, there have been precious few empirical studies analysing development-oriented research cooperation. A recent lirerature review notes that "... little of the material is the result of systematic studies of North-South research partnerships" (Spaapen 1999: 3; 16). Interviews and searches, which I have recently done in the United States, France, Sweden and the Netherlands, indicate that such a literature is absent; and that those studies that have been done are generally descriptive, evaluative or prescriptive. Jacques Gaillard (1999:13; 263), one of the best informed authors on this subject, writes: "Information in this field is often difficult to obtain [is often partial] and incomplete". Wesley Shrum, one of the outstanding researchers in the US in this field, 
recently told me (personal communication 2001) that he has been pleading for such research but could not get it funded. The same answer came from the Dutch Advisory Council for Scientific Research in Development Cooperation (RAWOO), which has organised numerous conferences on the topic.

\section{The lack of insight into donor-supported programmes}

Not only do we lack empirical reviews, we also lack solid policy reviews of donor-supported research. The central bookkeeper of such reviews is the Development Assistance Committee of the OECD. It does not include a budget line for resources committed to research and development (UNDP 2001: 110). The Canadian International Development Research Council (IDRC) has published data on its research efforts, and so have the Swedish Agency for Research in Economic Cooperation (SAREC) and the Dutch DGIS and RAWOO. In the case of the Netherlands there was a valiant effort in the early 1990 s, which was unfortunately discontinued.

These observations are not new. Lewis (1987) did pioneering work in the 1980s and concluded that international budger comparisons were hard to make. In 1994 a review concluded: "Efforts to map the capacity of development-related research at the national level [in the South, LB] continue to be negligible [...] Overviews of research funded by development agencies [...] are even more scarce" (Boer and Box 1994: 165). So much for the general picture.

Let us look at the Durch siruation. The budgets available for development-oriented research were and still are considerable. In 1989 (the first year for which information is available), some 170 research and research capacity building projects were identified, amounting to a total of US\$54 million. Add to this the subsidies for international research of about US\$ 8.5 million, making a total of about US\$ 62.5 million. In 2000 some US $\$ 36.4$ million 
were spent on 206 projects. The figures are not fully comparablebudget categories have changed, and so has the exchange rate-so few conclusions can be drawn. Let us therefore look at the raw data (in guilders) for the last few years.

Table 1. Expenditures on development oriented research and research capacity building, The Netherlands (1998-2000, in Dutch guilders)

\begin{tabular}{ll}
\hline Yeat & $\begin{array}{l}\text { Expenditure } \\
\text { (in million DFl) }\end{array}$ \\
1998 & 97.7 \\
1999 & 97.8 \\
2000 & 91.0 \\
2001 (est.) & $(90)$ \\
\hline
\end{tabular}

Source: Ministry of Foreign Affairs (DGIS/DCO), MIDAS data based on the respective budget codes, 18 September 2001

What do we see? First, there has been a gradual decline in support for research and related capacity building. Second, the present level of expenditure compares rather poorly with that in the late 1980 s. The case of the Netherlands may be indicative of a number of donors that have supported development-oriented research in the past, like Canada, Finland, Norway and Sweden. This is indeed a far cry from what European governments have been preaching in terms of transferring the benefits of the knowledge society to the South. It also stands in stark contrast with the needs identified in the recent Human Development Report, which: I mentioned before. The recent Danish initiative to bolster research in international cooperation is therefore an exception, rather than the rule (Udenrigsministeriet, 2001 ).

Even though the prioricy for research in intermational cooperation may be on the decline, these programmes continue to be a relevant source for such research. Take the case of a small country like the Netherlands again. Its total outstanding commitment to such research is in the order of NLG 1 . billion the exact figure 
being NLG $926,757,352$ (Ministry of Foreign Affairs 2001, personal communication). In a number of poor countries, this donor funding is just about the only funding available, because the national government gives no priority whatsoever to research. Take social science research in a middle-income country like South Africa. It has suffered reduction after reduction, making it increasingly dependent on donor funding. During a recent evaluation of Sanpad, one such donor programme, I was astonished to learn that it funds one-fifth to one-quarter of all social science research in South African higher educarion. Agricultural research in most African countries is almost exclusively donor funded, even though the rate of return is remarkable (for sub-Saharan Africa $33 \%$, for "all known locations" it is even $44 \%$, according to the UNDP 2001: p.44; see also p.110). Very few African leaders, like President Museveni of Uganda, are willing to spend on agricultural research or, for that matter, on any research aiming at human development.

Why is public funding of research for human development so low? The Human Development Report makes a damning diagnosis (UNDP 2001: 110-111). It argues that donors and recipients simply do not consider it a priority, blinded as they are by narrow national priorities. Too many small initiatives make for fragmented research, the results of which are not brought together. Donors wish to score with short-term results and compete among themselves. Recipient governments may prioritise military expenditures: if African governments had spent just one-tenth of their military outlays in 1999 on research it would have created a fund of US\$ 700 million in that year alone. (UNDP 2001)

The rather startling conclusion must be that international donor agencies have spent vast amounts of money on development-oriented research, without adequate empirical research accompanying this form of international cooperation. Research- " ers either were not interested, or could not interest funding agencies in supporting such research. Second, we may conclude that 
the funding agencies have not been particularly forthcoming in publishing data on their programmes. Third, we note that the recipient governments, with some notable exceptions, have not been interested in sponsoring development-oriented research.

The third assumption has therefore been falsified: donor policy cannot be based on the results of empiricall research, because such results simply do not exist. One note of caution is in order. I do not conclude that the money has been misspent, or that evaluations are lacking. For all we know, investments in scientific and rechnological research may have yielded high returns. We also know that donors do evaluate their programmes: these evaluations, however, are something different from solid empirical research and from general policy reviews.

\section{Other relevant literature: the economics of innovation}

The literature on the economics of technological innovation deals with a number of phenomena that are also relevant in development-oriented research. This is not the place to cover that literature, and neither I am the person to do so. Colleagues in Maastricht at Merit-Infonomics and UNU-Intech have published extensively on these issues; the Science Policy Research Unit in Sussex (UK), OECD-DSTI and others have also made significant contributions. I would like to mention just a few recent findings, which appear to corroborate the line of argument and show where a common research agenda can be found. The literature I am particularly interested in is the one on international collaborative arrangements between firms, and to a certain extent through so-called public-private partnerships in rechnology development.

The relevance of this literature lies in the observation that "public science paid for by governments increasingly conflicts with private or privatised science, which has its finger on the pulse of the world markets. [...] From being public property (which it still is), it is fast becoming private property that we may no longer 
wish to share" (Gaillard 1999: 312). The question then becomes: how do the worlds of public and priwate science (or technology development) relate to each other, especially in North-South rellations? Given the fact that private companies cannot take over completely, a dividing line needs to be drawn. In the words of Callon (as cited by Gaillard: 1999: 314) "without public science as a source of diversiry, the market $[. .$.$] will be condemned to yet$ greater convergence". Given the irrelevance of the poor countries to companies engaged in 'private science', the role of 'public science' is likely to be even greater. The question then becomes: how can a complementarity between public and private actors be found? Or, formulated in a more critical manner: how can a tragedy of the public knowledge 'commons' be averted? Paul David (2001), from whom I borrowed this formulation, notes that "the conduct of open, collaborative science [...] may be seriously jeopardised" by the consequences of European legal innovations in inteliectual property protection. This, I would submit, is one of the key questions that needs to inspire science and technology (S\&T) development policies at the bilateral, multilateral and (given the increasing importance of civil society in international cooperation) at the "civilateral' level. Such policies must take into account 'private science', yet have a clear view of the need for public support to maintain and develop the global commons of public knowledge.

We know that public expenditure has a positive effect on business research and development The OECD-STI (2000) has calculated that for the rich countries (assembled in the OECD) every public dollar generates US $\$ 1.70$ of research; tax incentives may also have positive effects, both in the OECD and elsewhere, provided that no direct funding is then given. Key features of a successful policy appear to be: massive and pluralistic government funding of programmes with high academic quality, allowing investment in long-rerm development of new fields (Pavirt 2000). One of the key factors determining the positive relationship 
between public and private is funding stability, which in turn breeds trust.

This links up with one of the principal conclusions of work on collaborative arrangements between firms at the international level: the arrangements need to have a long-term perspective. Briefly, some of the other lessons are:

Trust: Collaborative arrangements need a sufficiently long time horizon in order to breed trust." "Too many ventures are established to bridge gaps in short term resources, rather than for long term strategic fit" (Tidd and Lzumimoto 2001). If the arrangements are made for other short-term considerations (political or financial, as in European collaboration programmes) trust will not emerge (Marschan-Piekkari et al., 2001). Sustained international $R \& D$ collaboration between firms increases both the profitability and the stability of the agreement (Navarett and Carraro 1999: 168).

Dialogue: Collaborative arrangements, be they private-private, or private-public, need to be based on a policy dialogue that involves all interested parties (Mytelka 1998: 13). Many governments establish science and technology policies and partnerships without such dialogue. Knowledge transfer or exchange needs to recognize the different characteristics of knowledge users and producers (Cowan et al., 20011)

Differentiation: Collaborative arrangements are sector-specific. There is no general recipe. Knowledge generation and transfer in the service sector may require other user-producer linkages than in manufacturing (Cowan et al., 2001) or in agriculture (Peterson et al., 2001)

Culture: Such arrangements are culture-dependent and are embedded within national contexts. The division of labour between partners differs, as has been shown in studies of British and Japanese knowledge exchanges (Tidd and Izumimoto 2001)

Networks: Firms are eclectic in networking, and increasingly link up with parties they might have shurned before. Knowledge 
and information networks are fairly open, especially in those cases where knowledge is not a ppropriated in the form of patents. An example is the transnational seed company Pioneer-HiBred, which has in the area of biotechnology some 800 agreements with private and public agencies; these agreements can take different forms as in partmerships and networks. (see Pray and UmaliDeininger 1998, as cited in Chataway 1999?: 7).

One word about these novel forms of cooperation, and the terms that are used to denote them. The new literature abounds with terms like networks, linkages and partnerships. In their vagueness they may lose meaning. For the sake of clarity, I understand cooperation as a form of organised interaction towards a common end for mutual benefit. ${ }^{10} \mathrm{~A}$ newwork is a relatively loose form of cooperation in which coordination is done through horizontal exchanges of information, lacking a clear hierarchy and a long-term commitment. ${ }^{11}$ Linkage is a relatively structured form of long-term cooperation between institutions on the basis of an agreement, aiming at mutual benefit of the institutions involved. ${ }^{12}$ A partnership is a highly structured form of cooperation that "entails a long-term commitment and reflects a condition of mutual dependency [involving] a ser of normative rules, determining what behaviour is permissible and what constitutes a violation of trust. The rules are designed to facilitate exchange in a situation that would orherwise be open to exploitation". ${ }^{3}$ Twinning is a form of partnership between two, generally public, institutions to promote a common interest, which generally includes the exchange of services. ${ }^{14}$

Over the past two decades these forms of collaboration have been established in international cooperation in research. Especially in the official development assistance programmes of donor agencies, they are adopting an increasingly significant role. Although it is too early to draw final conclusions about these programmes, a few trends can be noted. 
Public support to scientific cooperation has been an increasingly significant factor, due to the declining budgets for research in poor countries and for development-oriented research in the North. Since the funding agencies have been able to call the tune, they have also had a great influence over the form that such cooperation takes. The notion of networks, for example, is strong in European programmes fostering collaboration between researchers in different European countries. Although there is lirtle research on the costs and benefits of such networks, they are a commonly accepred requirement for funding (Marschan-Piekkari 2001). The same model has been applied to cooperation between Europe and poor countries, leading to ad hoc alliances. It can be seriously questioned if the factor of trust was sufficiently created in the relations so developed.

Linkage between users and producers in research is another such requirement. Funding is increasingly made conditional on the involvement of users. Take biotechnology research sponsored by the Netherlands. It has been based for the past decade on the notion that user involvement needs to be promoted (Ulmanen 2001: chapter 3). This is hard to achieve in Europe, llet alone in countries like Zimbabwe or India. A preliminary review by Lotte Asveld (2001), a student-researcher from Maastricht, indicates that this difficulty is becoming the Achilles heel of development-oriented research. She shows that researchers, farmers and policymakers may all agree on the value of such involvement, yet it is hard or even impossible to realise. In practice, it has proven impossible to have a real dialogue in India between the highly educated biotech researchers and poor farmers. Knowledge networks between producers and users cannot be assumed, neither can they be ordained by funders. They need to be carefully constructed.

As long as empirical studies on the effectiveness of development-oriented research are lacking, such funding requirements as user involvement will allow for fads and for undue interest pro- 
motion. The problem is that the funding requirements are based on political desirability. Reality is then shaped according to the wishes of the funding agency, which are all powerful.

Having worked on both sides of the divide, in a development agency and in research, I would like to offer a personal reflection. In 1989 the then Minister for Development Cooperation, Jan Pronk, decided to revamp Dutch development policy. One of the priority areas he defined was development-oriented research. This became one of the pillars in the new policy, as it was formulated in the government white paper entitled A World of Difference (1990). Jan Pronk had been impressed by the argument for greater user involvement in research agenda setting and wanted it to be reflected in his policies, much in line with the thinking reflected in Gibbons' Mode 2, which I mentioned before (Boer and Box 1994).

Each of the major research programmes proposed under the new policy had to be tested on the criterion of stakeholder participation. Dutch funding was made conditional upon this, so that Dutch programmes throughout the 1990 s increasingly reflected this concern. The demand-led Multi-annual Multidisciplinary Research Programmes are the best indicators of this policy (Gaillard 1999: 139-140). The design of these programmes was left almost exclusively to the stakeholders in poor countries. It is too early to draw conclusions, but preliminary reviews indicate that two problems have emerged. First, the demand-led orienta tion assumes that adequate structures exist in the receiving country to translate such demand into a research agenda. Given the social distance between researchers and users that Lotre Asveld noted, this may not be the case. Second, how does one evaluate such research? If indeed it is user-led, who should be the evaluators, and what should be their criteria? ${ }^{15}$

Another approach is being followed in the South Africa-Netherlands Research Programme on Alternatives in Development (Sanpad), which started in 1997. This is a bilateral programme, 
which is based on dialogue between researchers, rather than on a strict interpretation of user, or demand-led agenda setting. The South African case is interesting because it involves both historically advantaged institutes (a euphemism for traditionally white institutions) and disadvantaged (or black) institutes. It is therefore a case in international cooperation in science and technology that reflects conditions in rich countries (as in the Gauteng Technology Hub in South Africa) and in poor ones (for example the Cape Flats). I have just had the pleasure to review that programme with my South African colleague Nazeema Mohamed. Our conclusion is that the programme has been able to build on common strengths in the two countries and is likely to produce significant contributions to research as well as to research capacity building.

In both programmes, the quality of the results depends on the quality of the dialogue between the partners involved. ${ }^{16}$ International cooperation in research needs to allow for such dialogue. Just as was found in the studies of firms working together in 'technology partnerships", we may assume that trust can only be built on the basis of long-term collaboration. The key question is therefore: how to promote dialogue among the different stakeholders such cooperation. This has been the very topic of an interesting European research programme, the results of which may affect European policymaking. ${ }^{17}$ The last part of my presentation will therefore deal with this European dimension of international cooperation in research and research on international cooperation.

\section{Towards a European approach?}

The cliche has it that Europe is largest in trade and largest in aid, with regard to poor countries. Is it also largest in its science and technology cooperation? I shall argue that its largeness is there, yet without largesse. 
Its largeness can be shown in different ways. European initiatives have been and are significant in terms of funding. In 1982 a Science and Technology for Development (STD) programme was created, which continued under different names. In that year the European Parliament voted a first special budget for this purpose, and it continued to do so until recently. The European potential was recognised and countries that until then had not had cooperative programmes, started developing them. This was done through collaborative programmes, involving at least two European partners and one from a developing country. It allowed the creation of European research networks, some of which became formalised. Notable examples are the European Association of Development and Training Research Institutes (EADI, with over 200 institutional members), and agricultural research networks like NATURA and ECART, or, in medical research, SHARED ${ }^{18}$ (Gaillard 1999: 81-84). European development policies therefore did have an effecr in Europe itself.

Europe also came to manifest itself increasingly in the global sphere. European funding for agricultural research became more and more coordinated through a European initiative group, which now contributes about half to the largest international research consortium (CGIAR). Regional research networks in Africa were also encouraged. ${ }^{19}$

In the mid-1990s, at the insistence of Michel Rocard, the European Parliament expanded the S\&T programmes and proposed that the Commission come up with a new initiative. It was felt that the existing efforts were not in line with the great importance to be attached to scientific or technological cooperation. This was true for the relations with the preferred partners in Africa, the Caribbean and the Pacific under the Lomé Convention, as well as for other countries in Asia and Latin America. It led to a flurry of initiatives aimed at strengthening a European S\&T policy for development to be embedded in general coopera* tion policies. A Foundation was proposed, policy dialogue was 
considered and the integration of $5 \& \mathrm{~T}$ policies into the general agreements was promoted. One interesting result of this initiative was the commissioning of a study on policy dialogue as an instrument for improving international cooperation in science and technology. It could be argued that most cooperation in research had been Europe-led, either by policymakers or by researchers. The questions we were asked as policy researchers were: How could a demand-led policy be developed, as had been done in the Nordic countries and the Netherlands? How could new ideas on the production of knowledge, as argued by Michael Gibbons in his Mode 2, be implemented? 20

A methodology was designed which started from the so-called STS perspective, based on the notion that science and technology are social constructions, embedded in the norms and values of a particular society. My colleague Professor Wiebe Bijker was asked to apply this methodology to a number of case studies, which were carried out by local researchers in the Dominican Republic, Ghana, Senegal, Uganda and Vietnam. The results were fascinating. It appeared that the policy processes in the respective countries had not been taken into account before. Cooperation without dialogue, in other words. The local researchers became aware of the marginal role that many stakeholders had played in the formulation of $S \& T$ policies and in international programmes, like the European ones. Finally, we became aware of the poor methodological base for cooperation in research, and of the lack of research on such cooperation. The question then becomes: what can one do with results like these?

This is where Europe may be large, but its 'largesse' is limited. The Rocard initiative was forgotten; the European Parliament did not follow it up. The European Foundation for Science and Tech. nology Development remained a proposal. The Commissioner for Development dropped the priority for science and technology. The INCO-DEV progranme was terminated. An advisory group for development was created ... and was never heard of again. 
The integration of science and technology priorities into country or regional programmes has succeeded in just one or two cases. Europe's promise remains a promise, but a promise forgotten is a promise broken.

Contrast this with the need for science and technology cooperation as argued in this year's Human Development Report, which I cited earlier. Contrast this with ambitious statements of European heads of state on the need for collaboration in new technologies like information, communication and biotechnology. Or just contrast it with the expectations that Europe has raised in the past two decades with programmes, which may have had their failings, yet they enabled Southern researchers to maintain their links with knowledge networks in the North.

I therefore fully agree with Roland Waast, that untiring advocate for greater coherence in European development policies, when he writes: "an instrument needs to be found, which could give the full power to science-aid in all its dimensions and which could coordinate the relevant actions in the different domains through one global strategy" (Waast in Gaillard 1999). He adds: "At the heart of it should be local capacity development". Waast wrote these words in 1996, and they are just as valid now as they were then. European policies were effective in bringing European researchers together, in presenting the European contributions to global consortia, and in developing exciting new approaches to policy dialogue. But the question remains whether European initiatives will be able to do what was learned in the world of business, as I noted before: to build trust through long-term research collabotation.

My conclusion must be that little can be expected from the European Union in the realm of science and technology development. Member States will need to take the initiative. A country like Denmark might take the lead, since it just produced a challenging policy statement (Udenrigsministeriet 2001). Other countries with comparable policies like France, Germany, the Nether- 
lands and the United Kingdom could join this group to continue the initiatives taken in the past by the European Commission. Countries like Switzerland and Norway, possibly even Canada and Australia have corresponding policies and might contribute to a coalition of the willing. This is not likely to come about by itself. It will take civil society pressure to bring our policymakers to realise such initiatives. Organisations like EADI, together with its sister organisations in Africa, Asia and Latin America will need to put pressure on national governments. Networks like NATURA and others can do so as well.

I wrote these lines in the aftermath of the attacks on New York and Washington. A topic like international cooperation may then seem irrelevant, perhaps even frivolous. Why reflect on these matters when the richest country on earth is preparing to go to war with the poorest of all? Does it make sense to speak about science at such a time? Does it make sense to argue in favour of a European research initiative when the world may be aflame?

Yes, it does. Provided the research is done respectfully. Respecting the values of the other, respecting the dialogue, respecting the need for a long time frame to build trust. European researchers have worked in the tropics for hundreds of years: first assisting trade relations, then assisting the colonial enterprise, then as part of that unique postwar phenomenon of development cooperation. It started with idealism and enlightened self-interest, and it grew into nerworks of knowledge and networks of trust. Just as the Japanese had a Dutch window on the world for over two centuries, Europeans now have African, Asian and Latin American windows on the world. We may even have a Khoisan window on the world, as Professor Bredekamp argued, based on his collaborative research with a European institute. Especially in these times we need good research for better understanding. One area in need of such studies is the field of social conflict. ${ }^{21}$

At a time that war cries resound, the quiet of reason and understanding is called for. If the new modes of knowledge pro- 
duction that I have argued for mean anything at all, it is that researchers in poor countries should be taken seriously. They are in position, they have not emigrated to the science and technology hubs elsewhere. They have invested in a good higher education, often in Europe or in North America. All they may expect from us now is that we honour the promise of knowledge exchange, the to and fro of understanding. They do not ask for fancy programmes, following the fads of yesterday. They have become disillusioned with our terms like partnership, ownership, or other ships that yet have to appear on the 'development-speak' horizon. ${ }^{22}$

They remind us that we must keep our promises. If they have studied in Europe, they would like to see opportunities for their children to do so as long as higher education in their own countries is starved of funds. Europe receives and sends out more 'foreign" students than any other continent. ${ }^{23}$ If we wish to maintain this proud record, in which we have an enlightened self-interest, ${ }^{24}$ we shall have to keep our public institutions open. The commercialisation of higher education is likely to increase if the current trends in the World Trade Organisation continue. Numerous schools in the US and the UK now receive a considerable part of their income from foreign student fees. In continental Europe, at a time of budget cuts, these examples are eagerly being followed. ${ }^{25}$

The commercialisation of higher education parallels the commercialisation of research, which is just as frightening from the point of view of international cooperation. ${ }^{26}$ 'The two trends in training and research are linked in those cases where universities become the eager holders of patents, and promotion in the universiry is based on profits realised. Free exchange of information will then be a thing of the past. International cooperation in science and technology will be reduced to the folly of daydreams. Global protection of the free exchange of knowledge is needed more than ever. ${ }^{27}$ 
There is nothing more practical than a good theory. Vawi Lier 11979 !

\section{CONCLUSION}

An inaugural address is supposed to reflect the state of the art in a particular field of studies and indicate the research and train ing agenda. Allow me to draw a few conclusions and implications. Given my background in policy practice I would like to draw some practical conclusions regarding the field of study, its European context and the policy implications in Dutch international cooperation and in the cooperation that Mastricht University practices.

There is nothing more practical than a good theory was the maxim that Rudie van Lier would impress on his students and colleagues. This founder of a critical school of socio-historical thought and practice at Leiden and Wageningen Universities played with the notion of praxeology - the theoretical reflection on policy practice, or the practical application of theorizing (Van Lier 1979: 10). He argued that we need

... a realistic sense of problems and versatile open minds. I think that ow of these operations real multi-disciplinary work will emerge and will later find its explicit theoretical foundation. Multidisciplinary efforts should be in the first place problem-oniented. (...) And this means that the sociologist or anthropologis* bas not only to be trained as a crafesman, but that be should be supported in bis action-oriented approach by a systematic praxeology, acience of practice.

The study of science and technology as social phenomena incorporates various schools of thought and brings together many disciplines. It is an exciring exercise to see how mechanical engineers collaborate with philosophers, medical scientists with sociologists, and economists with all of the disciplines mentioned. 
The discipline is multidisciplinary or it is not. It requires a realistic sense of problems, because that is the pragmatic starting point, which makes for its societal relevance. It calls for open minds that can transcend the order of one discipline, or of one scientific or technological culture. It is problem oriented in that it redefines societal problems in intellectual or scientific terms. In doing so it formulates intellectual problems on the basis of practice. In all this, it truly engages in problem-oriented learning - the basic pedagogical premise at Maastricht Universiry. Much of what Van Lier called "a systematic praxeology" I find in the social study of science and technology. I wish to contribute to this field in one particular area of research: the understanding of international cooperation in research - the field that deals with the conditions responsible for productive dialogue among scientists from very different backgrounds.

In this lecture I have tried to make a case for such research on programmes of international cooperation as a normal part of science and technology studies. Universities cannot do this alone, but with additional support from donors a lot can be achieved. The STS constructionist approach as developed by people like Wiebe Bijker and others can be applied to these programmes. A better understanding of research design and execution would allow for the realistic involvement of users, and prevent general policy prescriptions from overriding legitimate scientific demands. It would also prevent scientific free riding at the cost of user relevance. STS is therefore a good example of praxeology as a theory of practice, or the understanding of the user's logic. I do not start from one theoretical framework, because I agree with Michael Cernea (1991: 5) that "an overall theory of induced social development has as yet not been articulated".

We need to be careful to bridge the gap between theory and practice. For "the split... between those in academic teaching and basic research and those in development and applied work... weakens both sides. There is limited mutual intellectual empow- 
erment, and ittle deliberate building of the development-oriented enterprise..." (Cernea 1991: 3). This will be the exact task in a new Master"s specialisation that I am happy to announce today. It is the programme 'Bridging the Gap', which was officially approved by the European Master's Programme on Society, Science and Technology (ESST), which already boasts two other specialisations at Maastricht University. The programme aims to understand ways of bridging the science and technology gap between rich and poor countries. At the same time, it confronts students with the need to bridge the gap between theory and practice. If there was one reason for me to leave the area of policy and re-enter academia, it was teaching. I learn best when teaching. I thank the students from the ESST course for their help, and I hope I shall pass their tests.

The ESST course is an interesting example of emerging knowledge networks at the European level. We need more of these consortia of universities and technical colleges. We need the support of donor agencies to open them up to Southern researchers, as is happening in NATURA and Unitwin. They could be the bases for collaborative long-term programmes allowing Southern researchers to continue to work in own country, as in the Sanpad programme, which brought together Professor Bredlekamp and his European colleagues. If the bases are there, the funding could come from the European Commission, complying with the request made by Michel Rocard through his motion in the European Parliament. The time for grand programmes at the European level has passed; now is the time for focused programmes supporting existing networks.

At the Dutch level, I hope that we can learn lessons from existing programmes. A recent evaluation of the grand Multi-annual Multidisciplinary Research Programmes leads me to believe that purely demand-led research has its serious weaknesses. It does not solve the users' problems and may lead to poor research. Neither should we go back to a supply-led orientation in which Dutch 
researchers exclusively determine the priorities. Let us learn from programmes like Sanpad, which I have mentioned various times. These allow for informal contacts based on dialogue between researchers within a long-term framework with clear academic results spurred on by competition. Don't create new superstructures to coordinate this type of research; they are costly, they stifle creativity and make administrators out of researchers. Allow that unique construction, the Advisory Council for Scientific Research in Development Cooperation, to do its work. The RAWOO is highly appreciated beyond the borders of the Netherlands, yet within them, too few policymakers listen to its recommendations.

At the level of Maastricht University 1 plead for continued financial support to long-term collaborative projects in a limited number of fields of basic research (see Feill 1994: 447). These include the life sciences, informatics, international law and technology studies in a limited number of countries that muster adequate researcher interest. I sincerely hope that Maastricht will not follow the commercial approach, because a university is no consulting agency. Let us invest in a few specific MA professional and $\mathrm{PhD}$ programmes with support from the University to complement fellowships granted to young researchers from developing countries. This could be done through a Maastricht Institutional Network, involving the University, UNU, MSM and orher institutes as partners in collaborative programmes like a Maastricht Summer School in Science and Technology Studies, or a Maastricht Science and Technology Forum.

\section{Coda}

An inaugural lecture is not complete without some words of appreciation. I wish to thank first and foremost my teachers for having made me into what $\mathrm{I}$ am. They are many, and it would make little sense to mention them all. Allow me to mention just two, because they show my intellectual trajectory. One is William 
T. Jones, a philosopher at Pomona College in Claremont, California. He was the liberal arts teacher who shaped my intellectual curiosity. The other is Virgilio, a cassava cultivator annex street-sweeper in the highlands of the Dominican Republic. He showed me the value of what I called before 'local knowledge'. An experimenter at heart, he engaged me in a dialogue I hope to contimue in different ways.

When Wiebe Bijker first approached me to take up the present chair I wondered why. Why would a university be interested in someone who had been working in policy management? In his own style he replied: "Perhaps because of that". The longer we work together, Wiebe, the more I enjoy the dialogue. Reading your own inaugural lecture, makes you the author of brevity, the stimulator of curiosity. You wrote: "Technological culture is my unit of analysis. It transcends the technology of our culture and the culture of our technology. Technological culture is the enviromment we live in, the wocabulary we speak, the norms and values by which we judge and order" (Bijker 1995: 7). Who would not be jealous of the author of such clarity?

Dear colleagues in the Faculty of Cultural Sciences, your knowledge challenges any newcomer. When I first met Bertus de Rijke a decade ago he told me about a new faculty he had helped to set up. Bertus immediately reminded me of that old professor at Pomona College: the same wit, the same versatility of mind.

Wiel Kusters was first the poet to me, then the fellow-Limburger and now a colleague. I shall hear your poetry when you speak, I shall read your lips when you write.

Arnold Labrie is the great magician who draws on novels to write history, and on decadence to tackle purity. Your analysis of the Other in 19 th century novels said something about the growth of the nation state: it becomes frightening when one applies it to the Moor in modern society. 
Rein de Wilde: I have seen your critical mind in operation and enjoyed it. Your dissection of the Knowledge Cult is as precise as if an anatomist had done it.

I cannot mention all of the many orher colleagues in the Faculry. Let me just name one, who stands for all: Chris Leonards. Together we have worked on the course Globalisation and Inequality. You have done that following the finest traditions of Problem-Based Learning. You extend the knowledge network well beyond Maastricht, involving practitioners from all over the globe. Paul Tummers, in you I congratulate the Faculty with its secretariat and its staff; as a former administrator myself I find great pleasure in working with these professionals. I look forward to working with each of you in that singular plurality called the Faculty of Cultural Sciences.

Dear colleagues of the other faculties and of the International Institute of Infonomics: the work I do at this University could just as well have been in any of your faculties or institutes. Maastricht University does not have trans-faculty arrangements, with the exception of Gender Studies and the programme on Globalisation and Inequality. I hope we can break down the walls when needed. One special word for my colleagues at UNU Intech, especially Lynn Mytelka: we share so many interests that $\mathrm{I}$ hope to see at least some of our plans realised.

Two groups need special mention: the students and the University Board. I have known the students ever since I came to Maastricht in another post, about a decade ago. You are so international that at times it is hard to know in which language we should speak; you are so multidisciplinary that one vocabulary does not suffice. I hope you will keep me agile.

Last, but certainly not least, I wish to thank the Board of the University for its help in my appointment. I have come to respect Karl Dittrich as an intellectual manager who orchestrates ideas like a composer. Arie Kruseman, you are the fortunate successor to that illustrious ancestor who was a teacher among doctors, a 
practitioner among philosophers. It is an honour for me to be your adviser in some respects, and a member of the intellectual community that you represent. 


\section{REFERENCES}

Adeboye, Titus (1998) 'Africa' in UNESCO, World Science Report 1998 Paris (UNESCO): $176-181$

Alvares, Claude (1997)'Science' in Wolfgang Sachs (Ed) The development dictio" nary New Delhi (Orient Longman)

Asveld, Lotte (2001) Biotechnology and developmental aid: How democratic can technology be? Maastricht (Thesis, Maastricht University. Faculty of Culmaral Sciences)

Bass, T.A. (1996) 'Tndigenous science: a star in Africa's future' in: Science and the Future Britannica: 160-175

Boef, Walter de et al. (1993) Cultiwating knowledge: generic diversity, farmer experimentation and crop research London (Intermediate Technology Publications)

Boer, Leen \& Louk Box (1994) 'The tenuous interface: policymakers, researchers, and user publics: the case of The Netherlands development cooperation" Knowledge and Pollicy 6 (3\&4): 158-175

Brush, Steven (1998) "Bio-cooperation and the benefits of crop genetic resources: the case of Mexicar maize' World Development 26 (5) 755-766

Bunders, Joske F G \& Chandan Mukherjee (1997), North-Sourh research partnerships: redressing the imbalance" Leiden (Conference on research partnerships for sustainable developmenc)

Buskens, Vincent (1999) Social networks and trust Utrecht (Diss. Universiteit Utrecht)

Bijker, Wiebe (1995) Democratisering van de technologische cultuur Maastriciat (Orarie, Rijksuniwersiteit Limburg)

Ceccarelli, Salvatore er al. (1995) 'Farmers and cop breeders as parmers" in Eyzaguirre et al. 1995:99-116.

Chataway, Joanna (1999?) Building capacity in biotechnology: The role of networks and partnerships Geneva (UNCTAD/TTE/IIP/Misc.23)

Cowan, Robin, Lue Soete \& Oxana Tchervonnaya (2001) Knowledge transfer and the services sector in the context of the New Econony Maastricht (MERIT-Infonomics Research Memorandum Series)

David, Paul A. (2001) Tragedy of the Public Knowledge "Commons": Global science, intellectual property and the digial technology boomerang Maastricht (MERIT-Infonomics Research Memorandum Series)

Engel, Patal (1995) Facilitating innovation Wageningen (Diss., Agricultural University)

Eyzaguirre, Pablo 8 Masa Iwanaga (Eds.) (1996) Participarory plant breding Rome (Int") Plant Genetic Resources Institure)

Gibbons, Michael et al. (1994) The new production of knowledge London (Sage) 
Feil, Dirk (1994) "Sciuce and the Third World: an oupuranalysis" in Margaret Skutch al. Towards sustanable development: A liber amicorm for Eno W. Hommes Enschede Technology and Development group, University of Twente: $437-451$

Gallard, Jacques at a 1997 scientific communties in the developing world New Delwi (Sage Pubs Ifor newew see Marc Rothenberg in Technology and Culture 40.1 (1999) $171-172$ or hrp//muse ihu edu/denotech/40.1 br gallitard.tom I

Gallard, Jacques (1999) Lacooperation scientilque et technique awecles pays du Sud. Peut-on parager la acionce: Paris (Karthala)

Gast. Jan-Willem de (1995) "Exective summary" in Jan Willem de Gast (Ed) Linkages revisiod: higher education and development cooperation The Hague (NUFFlC, $1995: 43 \cdots 66$

Ginkel, Hans wan 1995 ) 'Urech Universty: a search for partiership' in Jan-Willem De Gast $1995: 309-322$

Harrss, J (1998) "Working together: the principles and practice of cooperation and partnership" in Comperition, co-ordination and co-operation... (The Open University)

Hillebrand, Wolfgang et al, 1994) Strengthening rechmological capability in developing countros, lessons from Gernan technical cooperation Berlin (German Development Institute) I wwwwbs.cs.tu-berlinde/user/jms/lessons. Triml

Koch, Gloria Veronica et al., Modace 'New approaches to science and technotogy capacity building and cooperation: an overview' (Mimeo, Nopublisher)

Krishma, V.V., Roland Wast \& Jacques Gallard (1998) "Globalizarion and sci. entific communties in deweloping countries World Science Report, Paris (UNESCO)

Lier, Radie A.J. van (1979) Discontimuiry in the social sciences, a plea for praxeology Wageningen Landbouwhogeschooly

Malcontent, P.A.M. 3 J.A.Nekkers (1999) "Inteiding: 'Doe wel en zhe net om' in J.A.Nekkers \& P.A.M.Matcoment (Red.) De geschiedenis wan vijfig jaar Nedenlandse ontwikkelingssamenwerking 1949 - 1999 Den Hag (Sdu Uigevers)

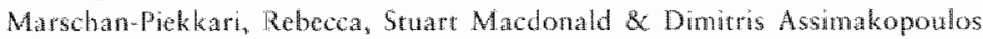
(2001) "In bed with a strangen finding partuers for collaboration in the European information techology programmé Science and Public Policy 28 (1): $68-78$

Meyar, Martin (2000) 'Does science push wechnology? Parents cing scientific lit" erarure" Reseanch Policy 29,3]

Mkandawire, Thandika 12000 "Non-organg intellectuals and "Leaming" in policy-naking Africa" in Jerker Carlsson \& Lennat Wohlgemurt (Eds.) Lowming in development comperation Srochom Amqvist \& wiksell: 205.212 
Mytelka, Lyon K., (1998) 'Upgrading and downgrading: Internatonal stratregic partnering ws. Mergers and Acquistions' Geneva (LOChllL - paper)

Navaretri, Giorgio Barba \& Carlo Carraro (1999) From learning to parmership: multinational R \& C coperation in depeloping countries" Bconomic innov"ation and new rechnologies $8: 137.173$.

OECD - 5TI (2000) The inapact of public R\&D expenditure on business R\&D, Paris (OECD 5TI Working papers - 200/4)

Pawit, Keirh (2000) 'Public policies to support basic researcls: what can the rest of the world learn from US theory and practice? (And what they should nor learn) SPRU Electronic Working Paper No. 531 www sussex.ac.uk/spm/. publicarions/imprint/sewps $53 /$ sewp 53 hrmll

Peterson, Warren et al. (2001) 'Merhods for planning effective linkages' ISNAR Briefing Paper 45 The Hague (ISNAR) \ www.cgiarorg/isnar/publica rions/briefing/Bp45.htm $]$

Ponsioen, J.A. (1968) National development: a sociological contriburion, The Hague (Institute of Social Sendies)

Pray, CE. \& D.Umali-Deininger (1998) "The private sector in agriculural research systems: will it fill the gap? Wonld Development $26(6) 1127 \times 1148$

Rostow, Walt (1960) The stages of economic growh Cambridge (University Press)

Scotr, John (2001) "Chirsa to boost recruirment of foreign scientists" see www. SciDew. net (Posted 2242001 )

Secord, Anne (1994) 'Corresponding interests: arrisans and gentlemen in nünteenth-century natural history British Journal for the History of Science, 27: 383408 .

Sharif, Nawaz (1999) 'Strategic role of technological self-reliance in develop" ment management' Technological Forecasting and Social Change 62: $219-238$

Shrum, Wesley M. (1996) Research capacity for sustainable development: report of a field study in Ghana, Kenya and Kerala (India), The Hague (RAWOO)

Spaapen, Jack (1999) 'North-South research partnerships: pitfalls and possibilities" in: North-Souch Research Partnerships: Issues and Challenges Trivandrum/The Hague (Rawoo)

Stigliz, Joseph E. (1999) 'Knowledge as a glohat public good' in Inge Katul er al. Global public goods: international cooperation in the $21^{\text {st }}$ century New York \& Oxford (Oxford Universiry Press) $308-325$

Tidd, Joseph \& Yasuhiko lzumimoto (2001) Knowledge exchange and learning through international joint venures: an Anglo-japanese experience' SPHU Electronic Working Paper No. 56 I ww. sussex.acuk/spru/publications/ingprint/sewps.56/sewp $56 . h \mathrm{mml}$

Udenrigsministerien (2001) Partnerships at the leading edge: a Danish vision for knowledge, rescarch and dewelopment Copenhagen (Danida) [w w w um edk/danida/partnerskab2000/partmershipattheleadingedge/] 
Ulmanen, Johanna (2001) [Working Title A comparison of biotechnology developmen policies in The Netherlands and Sweden! Maastriche (In Press, Masrer"s Thesis, ESST Programme

UNDP (2001) Human Development Report 2001: Making new technologies work for human development New York (Oxford University Press!

Wilde, Rein de (2001) De kenniscultus: over nieuwe vormen van voorvitgangsgeloof Maastricht (University Press) 


\section{MOTES}

1 wish to that the following indwiduats for heir help and stgestons in the

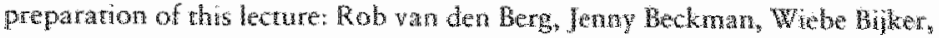

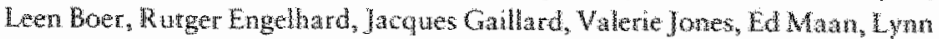
Mytelka, Ad Noten, Theo van der Sande; Westey Shrum ard Camont wat ner. Special thanks go to Babara de la Re Box-Lasocka for her critical contribution.

2 Ninoka, Yuki, "De 400 jat betrekking russen Nederland en Japan",400. Japanesem Dutch Retarions (1. The negoriations were with Wh Pry about we opening of Japar to the ourside world. Duth was used as the scientific language for rangaku or Dutch Studies, and remaned the of fich language for all contacts with the couside world men 1870 .

3 Interview wih H. Bredekamp, Cape Town, August 2001.

4 Fonsion 1968:53-54. For alater-day reformulation of amparable view, see Stigtitz 1999: 320: "... knowledge, aid and private capinal work together a successtul dovelopment programme: they are complementaty".

5 On the mamagenent implicarions of Mode 2, see Cibbots at al, 1994 : $161-165$.

6. 'Sneupers': dilettantes or anateurs in the Friesian Society for Arts and Sci ences. Ithank Rienlik Vermey tor this referene.

7 Se for a description of the phenology newrork in the Netherlands. It can be traced back to the work of Linnews in the 18 th centary, who stimulated observation networks, which involyed both professionals and non-probassional fieldworkers.

8 See for example De Boef et al. 1993; Eyzagurre et al. 1995 ; Cecardili at. 1995.

9 Trust can be seen as the "lubricant of copperation" Buskens 1999: 6). Trust at the individual level is the extent to which one party (tumstor) is willing to take the risk of the relation being mistused by the other (urusted) (after Buskens 1999: 9). At the social or normative level it is the "expectation that arises within a communty of regular, honest, and cooperative behavior, based on commonly shared norms, on the part of other members of that community" (Fukuyama $995: 26$ ).

10 See Dictionary of Sociology and Relared Scitences, Totowa, NJ (197\%), 1968.

11 See also Chataway 1999:" 9; for an application ro nesarch retworks in higher Education, see De Cast 1995: 54.

12 See De Gast 1995: 43; for a practical example in higher education, see Van Ginkel 1995: 313 .

13 Lorenz 1989:189, as aited in Chataway 1999: 9; for a specific example, sere the Whio/ Merck agreement in Costa Rica (Brush 1998: 757).

14 For an example, see Wan Ginkel (1995):317. 
15 For a revew of these programmes, see Batusta, Kaplan and Velho 2001 ). See also Bunders and Mukherje 1997 .

16 The acronym became INCO DC I International cooperation with Developing Coumeries and INCO-DEV.

17 See reports by L. Box, R. Engelhard and w.Biker on www demanding-innovation,org

18 ATURA: Newwork of European Agriculural Unversities and scierrific com plexwes related with agnicultural dewelopment; ECART: European Consortium Lor Agriculural Research for the Tropics (a consontim of parasatal or (semi-)prwate institutions) and SHARED: Scientists for Health and Research for: Development.

19 The total European contribution to the Consultavive Group on Intermational Agricultural Research (CGIAR) constiruted abour $45.5 \%$ of the total in 1996 (Gaillard 1999:83).

20 For the research proposal and the research reports see wwwdenanding-innowarion.org.

21 See for studies on conticit and contlict prewention in Europe and in the South.

22 This poine was eloquenty made to me by Dr Catherine Odora during a recent correspondence (Seprember 2001).

23 Europe has the largest and fastest growing foreign student population $139 \%$ of the global total, compared with $32 \%$ in the US and has a higher foreign student ratio (5.0 versus 3.0 in the US). Hurope also thas the second highest mumber of students going abroad (afer Asia), and in 1995 produced $27.6 \%$ of all foreign students (versus $3.7 \%$ for the US) (Gaillard $1999.32-35 ; 280-281$ ).

24 Foreign students benefit the receiving county in various ways. During their study they contribute tuinor, but also teaching and research assistance. Afer their sudy they may stay in the country of study and thus contribute to a brain gain. Later, they may be waluable partners in knowledge and infuence nerworks. In miversities in the Netherlands, doctoral candidates increasingly come from abroad, given the deching interest among Dutch students. The walue of these long-term relationships is based on long-term mutual interest, where the demand side was well articulated and the slipply side provided

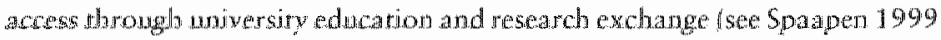
: 23 , also Tidd 2001).

25 Witness, for example, German federal policy towards the intemationalisacion of colleges and universities.

26 The commercialisation of knowledge is cleaty evident in the fic of angriculture. Agroultural wesearch is moreasingly privately funded; in the UK more than half $(57 \%)$ is conducted by private companies, compared with $36 \%$ in Ecodor and $32 \%$ in the Phippines (Pray and Umall-Deininger, 1998: 1132).

27 Ar the international level waste insearch and many other fundamental form of knowledge are not [... protected by an intellectual property egime. In these areas efficiency requires public support. And this public suppor must be 
at the global level" (Stiglitz 1999:320). In addition, we need to open up aceess to scientific publications through the Public Library of Science (see www Publiclibraryofscience.org) and provide gateways as in whw.scidev.net. 